\title{
EFEKTIVITAS KOMBINASI EFFLEURAGE MASSAGE DAN JAHE COMPRES BALL TERHADAP PENURUNAN TINGKAT NYERI PUNGGUNG IBU HAMIL TRIMESTER III
}

\author{
Poppy Fransisca Amelia ${ }^{1}$, Khofifa Ihwani ${ }^{1}$, Mei Lia Nindya Zulis Windyarti ${ }^{*}$ \\ 1STIKES Karya Husada Semarang \\ Email : poppymarlaen@gmail.com¹, Khofifaihwani13@gmail.com¹, mmeilia60@gmail.com ${ }^{*}$
}

Diterima : 4 Mei 2021 . Disetujui : 15 Juli 2021 . Dipublikasikan : 28 Juli 2021

\begin{abstract}
ABSTRAK
Perubahan fisiologis saat kehamilan salah satunya terjadi pada sistem musculoskeletal. Perubahan pada sistem muskuloskeletal dapat menyebabkan terjadinya nyeri tulang belakang pada kehamilan yang sering terjadi oleh ibu hamil terutama pada trimester III. ibu hamil diberbagai daerah Indonesia mencapai $60-80 \%$ ibu hamil mengalami nyeri. Mengetahui Efektivitas Kombinasi Effleurage Massage dan Jahe Compres Ball Terhadap Tingkat Nyeri Punggung Ibu Hamil Trimester III Di Praktik Mandiri Bidan Eka Semarang. Jenis penelitian ini adalah penelitian kuantitatif dengan rancangan one group pre-test- post-test Without Control Design, sampel penelitian sebanyak 18 responden dengan teknik purposive sampling, instrumen yang digunakan dalam penelitian adalah lembar observasi dan NRS dengan menggunakan data primer. Analisa data dilakukan dengan menggunakan uji paired $t$ tes. Kombinasi Efflurage Massage dan Jahe Compres Ball Efektif terhadap penurunan Tingkat Nyeri Punggung Ibu Hamil Trimester III dengan nilai pvalue $(0,000)$, dengan perbedaan nilai rata-rata sebelum sebesar 4,94 dan sesudah sebesar 1,66 sehingga efektif menurunkan nyeri unggung ibu hamil. Kombinasi Effleurage Massage Dan Jahe Compres Ball Efektif Terhadap Penurunan Tingkat Nyeri Punggung Ibu Hamil Trimeste III
\end{abstract}

Kata Kunci : : kombinasi efflurage massage; jahe compres ball; tingkat nyeri punggung.

\section{ABSTRACT}

One of the physiological changes during pregnancy occurs in the musculoskeletal system. Changes in the musculoskeletal system can cause spinal pain in pregnancy that often occurs by pregnant women, especially in the third trimester. pregnant women in various regions of Indonesia reaching $60-80 \%$ of pregnant women experience pain. To determine the effectiveness of the combination of Effleurage Massage and Ginger Compress Ball Against the Level of Back Pain of Third Trimester Pregnant Women in Independent Practice Eka Midwife Semarang. Research This research is a quantitative study with a one-group pre-test-post-test design without control design, a sample of 18 respondents with purposive sampling technique, the instruments used in the study were observation sheets and NRS using primary data. Data analysis was performed using paired $t$ test. The combination of Efflurage Massage and Ginger Compress Ball was effective in reducing the level of back pain in trimester III pregnant women with a value of pvalue $(0,000)$, with a difference in the average value before 4.94 and after 1.66 so that it effectively reduced maternal parental pain pregnant. The combination of Efflurage Massage and Ginger Compress Ball is effective in reducing the level of back pain in trimester III pregnant women

Keywords: combination of efflurage massage; ginger compress ball; level of back pain

\section{PENDAHULUAN}

Kehamilan adalah proses pertemuan dan persenyawaan antara sel mani (spermatozoa) dengan sel telur (ovum) yang menghasilkan zigot dan berakhir sampai permulan persalinan. Lamanya masa kehamilan normal adalah 280 hari (40 minggu atau 9 bulan 7 hari) dihitung hari pertama haid terakhir (Nurkhanifah 2012).
Pada kehamilan trimester III, terjadi perubahan meliputi perubahan fisiologis maupun psikologis dan keluhan, diantaranya adalah sakit punggung, payudara keluar cairan, konstipasi, pernafasan, sering kencing, masalah tidur, varises, kontraksi perut, bengkak, kram kaki, dan peningkatan cairan vagina. Perubahan pada sistem musculoskeletal dapat menyebabkan terjadinya nyeri tulang belakang pada kehamilan yang sering 
terjadi oleh ibu hamil terutama pada trimester III (Nurkhanifah 2012).

Prevalensi nyeri punggung pada kehamilan dilaporkan bervariasi dari 50\% di Inggris, Amerika, Canada, Turki, Korea, Israel, Skandinavia serta 70\% di Australia. Berdasarkan laporan Profil Data Kesehatan Indonesia tahun 2015. Diindonesia terdapat 5.298.285 orang ibu hamil, untuk wilayah kota Semarang 53.734 orang. Sedangkan diwilayah Provinsi Jawa Tengah jumlahnya ada 314.492 orang ibu hamil yang mengalami nyeri punggung. Ratih (2015) didapatkan bahwa ibu hamil diberbagai daerah Indonesia mencapai $60-80 \%$ ibu hamil mengalami nyeri punggung dengan intensitas sedang, , dan $32 \%$ ibu hamil mengalami nyeri punggung dengan intensitas ringan. Diantara semua wanita ini, 47-60 \% melaporkan bahwa nyeri punggung terjadi pada kehamilan 5-7 bulan (Saudia 2018).

Berdasarkan wawancara terhadap 10 ibu hamil trimester III Di Praktik Mandiri Bidan Eka Semarang, diperoleh informasi bahwa $80 \%$ ibu mengalami nyeri punggung. Dampak Nyeri punggung yang ibu rasakan menyebabkan lelah secara fisik maupun emosional serta terganggu aktivitas. Tujuan penelitian untuk mengetahui efektivitas kombinasi effleurage massage dan jahe compres ball terhadap penurunan tingkat nyeri punggung ibu hamil trimester III di praktik mandiri bidan Eka Semarang tahun 2019.

\section{METODE PENELITIAN}

Jenis penelitian ini adalah penelitian kuantitatif dengan rancangan quasi eksperimen (eksperimen semu) dengan model pendekatan one group pre-testpost-test Without Control Design yaitu eksperimental. Penelitian dilaksanakan dari awal persiapan pelaksanaan dan penyusunan laporan dari bulan Juli 2019 sampai dengan Januari 2020 di PMB Eka Setyowati STr.Keb.

Alat ukur yang digunakan adalah lembar observasi dan skala NRS, SOP pemberian Kombinasi Efflurage Massage dan Jahe Compres Ball. Analisa data meliputi analisa univariate menyajikan nilai Mean, standar deviasi, minimum dan maksimum serta analisis bivariat menggunakan karna data berdistribusi normal. Uji normlitas dilakukan menggunakan uji shapiro-wilk karena responden $\leq 50$ (18 orang). Etika penelitian terdiri dari informed consent, Anonimity, confidentiality dan Beneflence

\section{HASIL DAN PEMBAHASAN}

Tabel 1 Tingkat nyeri punggung ibu hamil sebelum dan sesudah di berikan,Kombinasi Efflurage Massage dan Jahe Compres Ball.

\begin{tabular}{lcccc}
\hline Tingkat nyeri & $\mathbf{n}$ & Mean & SD & Min-Maks \\
\hline Pre & 18 & 4,944 & $\pm 1,349$ & $3-7$ \\
Post & & 1,667 & $\pm 1,084$ & $0-4$ \\
\hline
\end{tabular}

Berdasarkan 1 dari 18 responden dapat diketahui bahwa tingkat nyeri punggung ibu sebelum diberikan kombinasi Efflurage Massage dan Jahe Compres Ball memiliki nilai rata-rata 4,9444, dengan nilai minimum 3, nilai maksimum 7 dan standar deviasi 1,34917 .
Selanjutnya, Tingkat nyeri punggung ibu sesudah diberikan kombinasi Efflurage Massage dan Jahe Compres Ball memiliki nilai rata-rata 1,6667, dengan nilai minimum 0 nilai maksimum 4 dan standar deviasi 1,08465 . 


\section{Tabel 2 Efektivitas kombinasi Efflurage Massage dan Jahe Compres Ball terhadap tingat nyeri punggung ibu hamil}

\begin{tabular}{|c|c|c|c|}
\hline Tingkat nyeri & Mean & SD & $\rho$ value \\
\hline Pre & 4,944 & $\pm 1,349$ & 0,000 \\
\hline Post & 1,667 & $\pm 1,084$ & \\
\hline
\end{tabular}

Berdasarkan tabel 2 dapat disimpulkan bahwa nilai rata-rata tingkat nyeri punggung ibu sebelum diberikan kombinasi Efflurage Massage dan Jahe Compres Ball sebesar 4,9444 dan setelah diberikan kombinasi Efflurage Massage dan Jahe Compres Ball sebesar 1,6667. Perbedaan tingkat nyeri punggung ibu berdasarkan uji paired t-test diperoleh nilai $\rho$ value sebesar 0,000 . Karena hasil yang didapat lebih kecil dari signifikansi yang ditetapkan yakni 0,05 , maka secara statistik terdapat perbedaan tingkat nyeri punggung ibu sebelum dan sesudah diberikan Efflurage Massage dan Jahe Compres Ball yang bermakna bahwa efektif terhadap penuruna tingkat nyeri punggung ibu hamil trimester III di PMB Eka Setyowati.

\section{PEMBAHASAN}

Hasil penelitian menunjukkan bahwa tingkat nyeri punggung ibu sebelum diberikan kombinasi Efflurage Massage dan Jahe Compres Ball memiliki nilai ratarata 4,9444. Sedangkan. Tingkat nyeri punggung ibu sesudah diberikan kombinasi Efflurage Massage dan Jahe Compres Ball memiliki nilai rata-rata 1,6667.

Nyeri punggung yang dialami ibu hamil dapat disebabkan oleh uterus yang semakin hari semakin membesar karena pertumbuhan janin maka pusat gravitasi pada wanita hamil akan berpindah kearah depan (lordosis). Sebagian besar nyeri punggung di sebabkan karena aktivitas fisik ibu seharihari yang berlebihan, ketika ibu hamil harus mengurus rumah tangga di samping itu juga ibu harus bekerja, sehingga menyebabkan ibu kelelahan. Kondisi ibu hamil sebelum diberikan kombinasi Efflurage Massage dan Jahe Compres Ball nyeri punggung yang ibu rasakan menyebabkan lelah secara fisik maupun emosional, tegang daerah punggung, sehingga terganggu aktivitas dan berdampak pada pola istrahat ibu (Saudia 2018). Hal ini sesuai dengan perubahan fisiologis yang dijumpai saat kehamilan salah satunya terjadi pada sistem musculoskeletal dapat menyebabkan terjadinya nyeri tulang belakang yang sering terjadi oleh ibu hamil terutama pada trimester III (Sarwono 2014).

Kombinasi Efflurage Massage Dan Jahe Compres Ball merupakan metode non farmakologi yang menjadi alternatif pilihan dalam membantu nyeri punggung kehamilan. Dari penelitian ini, tingkat nyeri punggung ibu hamil setelah diberikan kombinasi Efflurage Massage Dan Jahe Compres Ball mengalami penurunan tingkat nyeri punggung ibu hamil yang signifikan. Hal ini di sebabkan oleh adanya Efflurage Massage dapat meredakan nyeri pada punggung, dalam hal ini peredaran darah ibu akan mengalir lancar yang dapat meredakan rasa sakit secara alami dalam kehamilan. Efflurage Massage juga membuat ibu merasa senang dan rilex, sentuhan orang yang peduli menolong merupakan sumber kekuatan ibu serta kombinasi Jahe Compes Ball (Dhippayom 2015).

Jahe (Zingibercassumunar) mengandung senyawa gingerol dan shogaol yaitu senyawa panas dan pedas yang terdapat di dalam jahe. Sehingga ketika diberikan kompres jahe sensasi pedas dari kompres jahe tersebut akan mengurangi peradangan, 
meredakan nyeri, kaku, dan spasme otot. Senyawa gingerol telah terbukti mempunyai aktivitas sebagai antipiretik, antitusif, hipotensif anti inflamasi dan analgesic (Kuswanti 2014).

Hasil penelitian ini sejalan dengan penelitian yang dilakukan oleh Cristinawati (2017) yang mengatakan Kompres hangat jahe bisa menggurangi nyeri punggung pada ibu hamil trimester III dengan nilai $\rho$-value $=0,000(\rho<0,05)$.

Hal ini juga didukung oleh penelitian yang di lakukan oleh Loice Noni dkk (2018) mengatakan bahwa Herbal Compres Ball efektif untuk menurunkan nyeri otot pada lansia. Penelitian ini menunjukkan bahwa Herball Compres Ball sama baiknya dengan penggunaan obat ibuprofen dalam hal menurunkan nyeri dan bermanfaat dalam mengurangi dampak negative penggunaan terapi farmakologi dengan nilai $\rho$-value $=0,000(\rho<0,05)$.

\section{SIMPULAN DAN SARAN}

Simpulan : Kombinasi Efflurage Massage dan Jahe Compres Ball Efektif terhadap Penurunan Tingkat Nyeri Punggung Ibu Hamil Trimester III dengan nilai $p=0,000(p<0,05)$.

Saran Tenaga kesehatan khususnya bidan dapat menjadikan hasil penelitian ini sebagai masukan sekaligus alternatif upaya peningkatan kualitas dan derajat pelayanan kesehatan dengan menerapkan metode non farmakologi selain menggunakan metode farmakologi terutama pada ibu hamil normal dan khususnya pada ibu hamil dengan kebutuhan terhadap perawatan nyeri punggung yaitu dengan Efflurage Massage dan Jahe Compres Ball

\section{DAFTAR PUSTAKA}

Kuswanti, Ina. 2014. Asuhan Kehamilan. Yogyakarta: Pustaka Pelajar
Mulyani, N., \& Silalahi, U. A. (2018). Pengaruh Kompres Air Hangat Dan Air Dingin Terhadap Nyeri Tulang Belakang lbu Hamil Trimester lii Di Wilayah Kerja Puskesmas Rajapolah Tahun 2018. Jurnal Kesehatan Bidkesmas Respati, 2(9), 18-27.

Saudia, B. E. P., \& Sari, O. N. K. (2018). A Difference On The Effectiveness Of Endorphin Massage With Warm Compress Therapy To Decrease Mother's Back Pain During Third Trimester Of Pregnancy At All Public Health Center In Mataram. Jurnal Kesehatan Prima, 12(1), 23-29.

Noni, L., Baeha, F., Pujiastuti, M., \& Pane, J. (2018). Pengaruh Herbal Compress Ball Terhadap Penurunan Nyeri Otot pada Lansia di Upt Pelayanan Sosial Lanjut Usia Binjai Tahun 2018 Program Studi Ners STIKes Santa Elisabeth Medan Staf Pengajar STIKes Santa Elisabeth Medan. Mutiara Ners, 1, 81-89.

STIKes, M. H. (2015). Prosiding Seminar Nasional: Profesionalisme Tenaga Kesehatan Berbasis Kelautan Menuju Mea 2015.

Prawiharjo, Sarwono. 2014. IImu Kebidanan. Jakarta: Bina Pustaka.

Dhippayom, T., Kongkaew, C., Chaiyakunapruk, N., Dilokthornsakul, P., Sruamsiri, R., Saokaew, S., \& Chuthaputti, A. (2015). Clinical effects of Thai herbal compress: a systematic review and metaanalysis. Evidence-Based Complementary and Alternative Medicine, 2015.

Chandra, B. (2008) Metodologi Penelitian Kesehatan. Jakarta: Penerbit Buku Kedokteran EGC.

Andryani, Y. (2019). EFEKTIVITAS EFFLEURAGE MASSAGE UNTUK MENGURANGI NYERI PUNGGUNG PADA IBU HAMIL TRIMESTER III DI RB Cl SEMARANG. Jurnal IImu dan Teknologi Kesehatan, 10(1).

Issarata, T., \& Lekskulchai, O. (2013). The Efficacy of Thai Massage in Relieving Low Back Pain among Pregnant Women in the Third Trimester. Journal of Thai Traditional \& Alternative Medicine, 11(2), 145-151.

Izza, S. (2014). Perbedaan Efektifitas Pemberian Kompres Air Hangat dan Pemberian Kompres Jahe Terhadap Penurunan Nyeri Sendi pada Lansia di Unit Rehabilitasi Sosial Wening Wardoyo Ungaran. Skripsi: STIKES Ngudi Waluyo Ungaran. 
Abyu, D. R., \& Prisusanti, R. D. (2017). Pengaruh Pemberian Kompres Air Hangat Terhadap Intensitas Nyeri Punggung lbu Hamil Trimester III. Wijaya Kusuma Malang Journal, 1(1), 11-16.

Dhippayom, T., Kongkaew, C., Chaiyakunapruk, N., Dilokthornsakul, P., Sruamsiri, R., Saokaew, S., \& Chuthaputti, A. (2015). Clinical effects of Thai herbal compress: a systematic review and metaanalysis. Evidence-Based Complementary and Alternative Medicine, 2015.
Richard, S. D. (2017). TEHNIK EFFLEURAGE DAN KOMPRES HANGAT EFEKTIF MENURUNKAN NYERI PUNGGUNG IBU HAMIL. JURNAL STIKES RS Baptis Kediri, 10(2).

Setiawati, I. (2019, November). Efektifitas Teknik Massage Effleurage Dan Teknik Relaksasi Terhadap Nyeri Punggung Pada Ibu Hamil Trimester III. In Prosiding Seminar Nasional: Pertemuan Ilmiah Tahunan Politeknik Kesehatan Karya Husada Yogyakarta (Vol. 1, No. 1, pp. 1-7). 